\title{
Genetic diversity in Vernonia amygdalina Delile accessions revealed by random amplified polymorphic DNAs (RAPDs)
}

\author{
PETER O. AIKPOKPODION ${ }^{* 1}$, JOAN ABEBE ${ }^{1}$, DAVID IGWE ${ }^{2}$ \\ ${ }^{1}$ Department of Genetics and Biotechnology, Faculty of Biological Sciences, University of Calabar, PMB 1115 Calabar, Nigeria \\ ${ }^{2}$ International Institute of Tropical Agriculture, Ibadan, Nigeria
}

\begin{abstract}
The bitter leaf plant (Vernonia amygdalina Delile) is an indigenous shrub tree species highly cultivated in West and Central Africa for its nutritional and medicinal values. We used 10 random amplified polymorphic DNA (RAPD) markers to assay 30 accessions of $V$. amygdalina Delile ecotypes (bitter and less bitter leaves, respectively) collected from the southern states of Nigeria (Cross River, Edo, and Oyo). The results obtained showed that RAPD markers were highly polymorphic (98.0\%) and generated a total of 29 PCR bands - ranging from two for OPH-03 to 10 for OPB-01 primers. The polymorphic information content was highest for the OPB-01 primer (0.768). Moreover, gene diversity $\left(H_{e}=0.800\right)$ was high, and cluster analysis delineated the accessions into seven groups, which indicated that a significant genetic diversity was present among the accessions studied. The geographical distinctness observed among the accessions indicated a possible effect of plant isolation by distance and a restricted gene flow. The results obtained in this study showed a genetic variability that could be exploited for varietal delineation and used to improve this indigenous species in Nigeria. This is the first report on the molecular study of genetic diversity in $V$. amygdalina.
\end{abstract}

Key words: Vernonia amygdalina, genetic diversity, RAPD - random amplified polymorphic DNA

\section{Introduction}

The bitter leaf plant, Vernonia amygdalina Delile, is a member of the genus Vernonia that comprises approximately 1000 species of forbs and shrubs belonging to the family Asteraceae - the largest of the tribe Vernonieae. It grows mainly in South America and Africa (Izevbigie et al., 2003). V. amydalina is highly cultivated in West and Central Africa and can be consumed in various forms. The leaf, stem, and root extracts of the plant are used for various medicinal, herbal, and nutritional purposes (Ijeh and Ejike, 2011).

$V$. amygdalina is most commonly used in traditional medicine, where leaf decoctions are used to treat fever, malaria, diarrhea, dysentery, hepatitis, and cough, as a laxative, and as a fertility inducer (Ucheck, 2004). The plant has acquired special relevance recently, because it has been shown to possess potent anti-tumorigenic properties in clinical studies (Izevbigie et al., 2004). Phar- macological studies in animals have shown that the leaf extract has both hypoglycemic and hypolipidemic properties and, thus, could potentially be useful in the management of diabetes mellitus (Akah and Okafor, 1992; Ebong et al., 2008). Nutritionally, in the tropics, V. amygdalina is used mainly to make soups as well as an appetizer and a febrifuge (Ijeh et al., 1996; Iwu et al., 1996).

Generally called bitter leaf, some variations have been observed in the level of bitterness, ranging from very bitter to less bitter, with the "bitter" type possessing a deep green coloration and a deep bitter taste and the "less bitter" type possessing a fairly light green coloration with little or no bitter taste. Despite the usefulness of various parts of the plant as a remedy against several diseases, to date, there is no information available in the literature with regard to the genetic variation among accessions or different types of $V$. amygdalina. This study was, therefore, conducted with the objective

\footnotetext{
* Corresponding author: Department of Genetics and Biotechnology, Faculty of Biological Sciences, University of Calabar, PMB 1115 Calabar, Nigeria; e-mail: paikpokpodion@gmail.com
} 
Table 1. Thirty $V$. amygdalina accessions used for the study with a description of the ecotype and collection sites in Nigeria

\begin{tabular}{|c|c|c|c|c|c|c|c|c|}
\hline & $\begin{array}{l}\text { Sample } \\
\text { name }\end{array}$ & Ecotype & State & $\begin{array}{c}\text { Local government } \\
\text { area }\end{array}$ & $\begin{array}{l}\text { Latitude } \\
{\left[{ }^{\circ} \mathrm{N}\right]}\end{array}$ & $\begin{array}{l}\text { Longitude } \\
{\left[{ }^{\circ} \mathrm{E}\right]}\end{array}$ & $\begin{array}{l}\text { Alt. } \\
{[\mathrm{m}]}\end{array}$ & Region \\
\hline 1 & VA-1E & bitter & Edo & Oredo & $06^{\circ} 44.567$ & $006^{\circ} 07.263$ & 41 & south south \\
\hline 2 & VA-2E & bitter & Edo & Oredo & $06^{\circ} 44.811$ & $006^{\circ} 07.601$ & 55 & south south \\
\hline 3 & VA-3E & bitter & Edo & Oredo & $06^{\circ} 44.507$ & $006^{\circ} 07.201$ & 47 & south south \\
\hline 4 & VH-4E & less bitter & Edo & Oredo & $06^{\circ} 44.470$ & $006^{\circ} 07.201$ & 78 & south south \\
\hline 5 & VH-5E & less bitter & Edo & Esan west & $06^{\circ} 36.340$ & $006^{\circ} 14.070$ & 307 & south south \\
\hline 6 & VA-6E & bitter & Edo & Esan west & $06^{\circ} 36.217$ & $006^{\circ} 14.103$ & 310 & south south \\
\hline 7 & VA-7E & bitter & Edo & Esan west & $06^{\circ} 36.487$ & $006^{\circ} 14.312$ & 318 & south south \\
\hline 8 & VA-8E & bitter & Edo & Esan west & $06^{\circ} 36.587$ & $006^{\circ} 14.261$ & 308 & south south \\
\hline 9 & VA-9E & bitter & Edo & Esan west & $06^{\circ} 44.780$ & $006^{\circ} 07.061$ & 372 & south south \\
\hline 10 & VH-10E & less bitter & Edo & Esan central & $06^{\circ} 44.234$ & $006^{\circ} 13.136$ & 405 & south south \\
\hline 11 & VA-11E & bitter & Edo & Esan central & $06^{\circ} 45.235$ & $006^{\circ} 05.328$ & 373 & south south \\
\hline 12 & VA-12E & bitter & Edo & Esan central & $06^{\circ} 44.701$ & $006^{\circ} 07.103$ & 376 & south south \\
\hline 13 & VA-13I & bitter & Oyo & Akinyele & $06^{\circ} 44.116$ & $005^{\circ} 12.091$ & 48 & south west \\
\hline 14 & VA-14I & bitter & Oyo & Akinyele & $06^{\circ} 44.317$ & $005^{\circ} 12.110$ & 42 & south west \\
\hline 15 & VH-15I & less bitter & Oyo & Akinyele & $06^{\circ} 44.367$ & $005^{\circ} 12.101$ & 40 & south west \\
\hline 16 & VA-16I & bitter & Oуо & Akinyele & $06^{\circ} 44.461$ & $005^{\circ} 12.163$ & 80 & south west \\
\hline 17 & VH-17I & less bitter & Oyo & Akinyele & $06^{\circ} 44.613$ & $005^{\circ} 07.204$ & 87 & south west \\
\hline 18 & VH-18I & less bitter & Oyo & Akinyele & $06^{\circ} 44.473$ & $005^{\circ} 07.211$ & 81 & south west \\
\hline 19 & VH-19C & less bitter & Cross river & Biase & $05^{\circ} 37.940$ & $008^{\circ} 01.062$ & 28 & south south \\
\hline 20 & VA-20C & bitter & Cross river & Biase & $05^{\circ} 37.980$ & $008^{\circ} 01.026$ & 16 & south south \\
\hline 21 & VA-21C & bitter & Cross river & Biase & $05^{\circ} 37.859$ & $008^{\circ} 00.965$ & 23 & south south \\
\hline 22 & VH-22C & less bitter & Cross river & Biase & $05^{\circ} 38.060$ & $008^{\circ} 01.096$ & 21 & south south \\
\hline 23 & VA-23C & bitter & Cross river & Biase & $05^{\circ} 36.915$ & $008^{\circ} 02.798$ & 39 & south south \\
\hline 24 & VA-24C & bitter & Cross river & Akamkpa & $05^{\circ} 24.105$ & $008^{\circ} 13.358$ & 102 & south south \\
\hline 25 & VA-25C & bitter & Cross river & Akamkpa & $05^{\circ} 24.101$ & $008^{\circ} 13.334$ & 98 & south south \\
\hline 26 & VH-26C & less bitter & Cross river & Akamkpa & $05^{\circ} 22.061$ & $008^{\circ} 16.373$ & 89 & south south \\
\hline 27 & VA-27C & bitter & Cross river & Calabar south & $04^{\circ} 57.517$ & $008^{\circ} 20.598$ & 52 & south south \\
\hline 28 & VA-28C & bitter & Cross river & Calabar south & $04^{\circ} 57.598$ & $008^{\circ} 20.413$ & 48 & south south \\
\hline 29 & VH-29C & less bitter & Cross river & Calabar south & $04^{\circ} 57.505$ & $008^{\circ} 20.593$ & 63 & south south \\
\hline 30 & VA-30C & bitter & Cross river & Calabar south & $04^{\circ} 57.403$ & $008^{\circ} 20.512$ & 42 & south south \\
\hline
\end{tabular}

of determining the genetic variation and molecular diversity in $V$. amygdalina types available in Nigeria by using random amplified polymorphic DNA (RAPD) markers.

\section{Materials and methods}

\section{Sample collection}

Leaf samples of $V$. amygdalina used for this study were collected from three states in the southern part of
Nigeria - namely, Cross River $(n=12)$, Edo $(n=12)$, and Oyo ( $n=6$; Table 1$)$. A total of 20 bitter and 10 less bitter types of $V$. amygdalina samples were randomly collected from different locations within a total of eight Local Government Areas (LGA), with due consideration for a representation of the two main ecotypes (bitter and less bitter types) as identified by the locals during collection. The samples were preserved in a fresh state in her- 
Table 2. Sequences of Operon RAPD markers used in the study

\begin{tabular}{c|c}
\hline Primer name & Sequence $\left(5^{\prime}\right.$ to $\left.3^{\prime}\right)$ \\
\hline OPB-01 & GTTTCGCTCC \\
\hline OPB-14 & TCCACTCTAA \\
\hline OPH-03 & AGACGTCCAC \\
\hline OPH-04 & GGAAGTCGCC \\
\hline OPT-15 & GGATGCCACT \\
\hline
\end{tabular}

metic containers using dry ice before being taken to the laboratory for analyses.

\section{DNA extraction}

Young leaves weighing between 100 and $200 \mathrm{mg}$ were ground into a powder using liquid nitrogen, and DNA extraction was done in accordance with a modified Dellaporta protocol (Dellaporta et al., 1983). The extracted DNA samples were quantified using $1.5 \%$ agarose gel electrophoresis and spectrophotometry.

\section{Polymerase Chain Reaction (PCR) amplifications with RAPD markers}

PCR amplification consisted of $4 \mu 150 \mathrm{ng} / \mu 1 \mathrm{DNA}$, $2.5 \mu \mathrm{l} 10 \times$ buffer (Bioline, Madison, USA), $1.5 \mu \mathrm{l}$ $50 \mathrm{mM} \mathrm{MgCl}{ }_{2}$ (Bioline, Madison, USA), $2 \mu 12.5 \mathrm{mM}$ dNTPs (Bioline, USA), $0.2 \mu 1500$ U DNA polymerase (Bioline, Madison, USA), and $1 \mu 110$ pm each RAPD primer (Table 2), and $1 \mu \mathrm{l}$ DMSO. PCR samples were adjusted to a total volume of $25 \mu \mathrm{l}$ by adding $12.8 \mu \mathrm{l}$ DEPCtreated water (Invitrogen Corporation, USA). The PCR cycling profile used for the reaction comprised an initial DNA denaturation step at $94^{\circ} \mathrm{C}$ for 5 min, 44 cycles of $94^{\circ} \mathrm{C}$ for $30 \mathrm{~s}$; annealing temperature at $49^{\circ} \mathrm{C}$ for $1 \mathrm{~min}$, and final extension at $72^{\circ} \mathrm{C}$ for $1 \mathrm{~min}$, and, finally, an 8 min extension at $72^{\circ} \mathrm{C}$ was maintained.

\section{Data analysis of RAPD profile}

The data matrix of RAPD profiles (Fig. 1) for fragments of similar size from each individual were scored as either the presence (1) or absence (0) of band. Data obtained from scoring the RAPD bands were used for the genetic similarity matrix using Jaccard's similarity coefficient (Jaccard, 1908). The polymorphic information content (PIC) of the markers used was calculated using the method propounded by Botstein and coworkers (1980). The phylogenetic relationship was determined by a cluster analysis using an unweighted pair-group method with arithmetic averages (UPGMA) with the NTSYS-pc software version 5.0.157.

\section{Results}

\section{Gene diversity and polymorphism}

A total number of 29 bands were detected from the five decamer primers used on the 30 accessions that were assayed (Table 3 ). The number of amplified bands (Fig. 1) ranged from two for OPH-3 to 10 for OPB-01 primers. The allelic frequency was highest (0.60) for OPB14 and OPH-14 and lowest for OPH-03 and OPB-01. Gene diversity $\left(H_{e}\right)$ was significantly high among the samples studied, as revealed by OPB-01 $\left(H_{e}=0.800\right)$, followed by OPH-04 $\left(H_{e}=0.720\right)$. OPH-03, on the other hand, showed the smallest diversity among the studied samples $\left(H_{e}=0.300\right)$. The polymorphism information content followed the same trend (Table 3 ); it was highest in OPB-01 (0.768) and lowest in OPH-03 (0.268). A dendrogram prepared on the basis of results from a cluster analysis (Fig. 2) showed that the accessions studied were grouped into seven main clusters. Cluster 1 consisted of six accessions of bitter and less bitter $V$. amygdalina types, obtained mainly from the southern parts of Edo State in Oriedo LGA. Cluster 2, on the other hand, consisted of accessions of bitter and less bitter $V$. amygdalina plants from the coastal southern part of the Cross River State in Calabar South LGA. Accessions obtained from Biase and Akamkpa LGAs in the humid forest vegetation of Cross River State made up Cluster 3. Cluster 4 consisted of accessions from the three main states and was the most diverse among all seven clusters. Cluster 5 consisted of accessions obtained from Akinyele LGA, Ibadan in Oyo State. Clusters 6 and 7 appeared as out-groups with distinct grouping away from other clusters. All four accessions grouped in these three clusters were obtained from the northerly and higher altitude regions of Edo State in Esan Central and Esan West LGAs.

\section{Discussion}

In this study, RAPD analyses provided an insight into the genetic diversity, genetic structure, and distribution of two ecotypes of $V$. amygdalina ("Bitter" and "Less bitter") obtained from three southern states of Nigeria (Cross River, Edo, and Oyo). Previously, random 


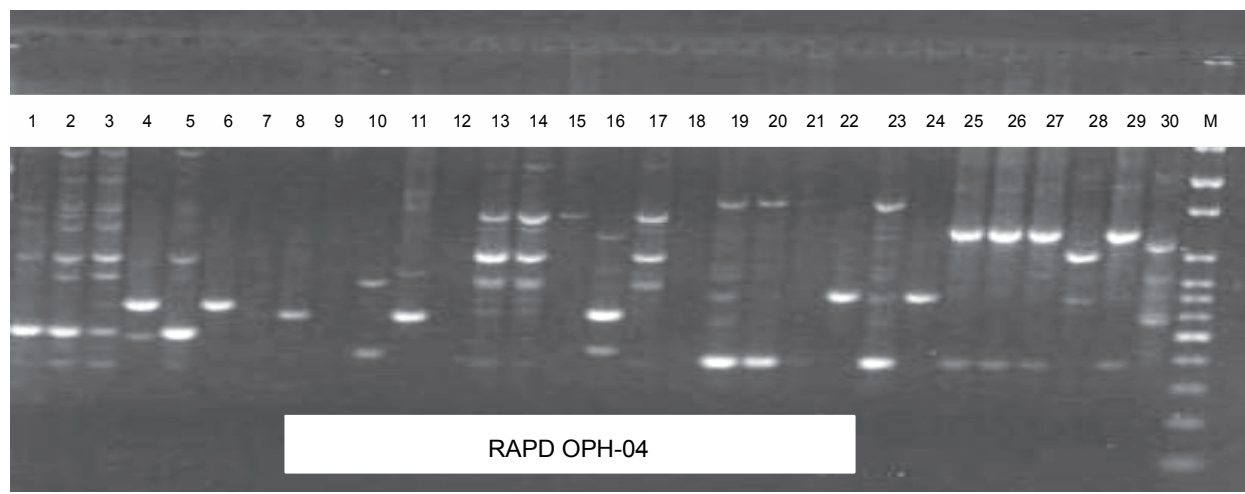

Fig. 1. Amplification patterns from $V$. amygdalina accessions (1-30) using the RAPD OPH-04 primer. $M$ is the marker of molecular weight (100-bp DNA ladder and PUC/18 Sau 3AI-PUC 18/Taq1 digest)

Table 3. List of band frequencies generated through amplification

\begin{tabular}{c|c|c|c|c|c}
\hline Marker & $\begin{array}{c}\text { Band } \\
\text { frequency }\end{array}$ & $\begin{array}{c}\text { Sample } \\
\text { size }\end{array}$ & $\begin{array}{c}\text { Number } \\
\text { of bands }\end{array}$ & $\begin{array}{c}\text { Gene } \\
\text { diversity }\end{array}$ & PIC \\
\hline OPB-14 & 0.600 & 30 & 3 & 0.480 & 0.4992 \\
\hline OPB-01 & 0.200 & 30 & 10 & 0.800 & 0.7680 \\
\hline OPH-14 & 0.600 & 30 & 5 & 0.560 & 0.3648 \\
\hline OPH-04 & 0.400 & 30 & 9 & 0.720 & 0.6720 \\
\hline OPH-3 & 0.200 & 30 & 2 & 0.300 & 0.2680 \\
\hline
\end{tabular}

PIC - polymorphism information content

amplified polymorphic DNA (RAPD) markers were used to determine the extent of the genetic diversity in different plant species, including sweet cherry (Lisek et al., 2005), citrus (Baig et al., 2009), capsicum (Rabelo da Costa et al., 2006), pinus (Monteleone et al., 2006), and even in Leishmania parasites (Mkada-Driss et al., 2014), and provided useful information for the exploitation of available genetic variability. The large number of alleles and the high gene diversity $(H e=0.800)$ observed in this study (Table 3 ) proved that significant genetic variability occurs among the $V$. amygdalina species grown in Nigeria.

Five of the polymorphic RAPDs decamer primers used in this study (Table 2) were found useful for the delineation of accessions collected from different parts of the country. These observations are similar to those reported by Lisek and coworkers (2005) wherein, by using six primers, it was possible to distinguish all cultivars of the sweet cherry studied. Similarly, Hsiang and coworkers (2000) have successfully used seven RAPD primers to distinguish among juniper and cedar cultivars. All markers used in this study were highly polymorphic (98.0\% polymorphic bands), similarly to the report of Shafie and coworkers (2009) who detected higher polymorphic bands (95.60\%) in RAPD markers than in intersimple sequence repeat (66.67\%) markers in Artemisia capillaris.

The seven clusters created during the cluster analysis (Fig. 2) showed that plants within the same location were generally distinct from those from other locations, even within the same state. Samples within the same local government areas were generally less diverse, with the exception of a few cases, as was found for materials from Edo State. It is intriguing to find that, within the same state of Cross River, Vernonia accessions obtained from Biase and Akamkpa LGAs were classified in Cluster 3 and were distinct from the tested accessions from Calabar South that were classified under Cluster 2 . A similar trend, and in fact a greater genetic diversity, was observed among Vernonia accessions collected from Edo State. All accessions obtained from Oriedo LGA were clustered in Cluster 1 and were distinct from those 


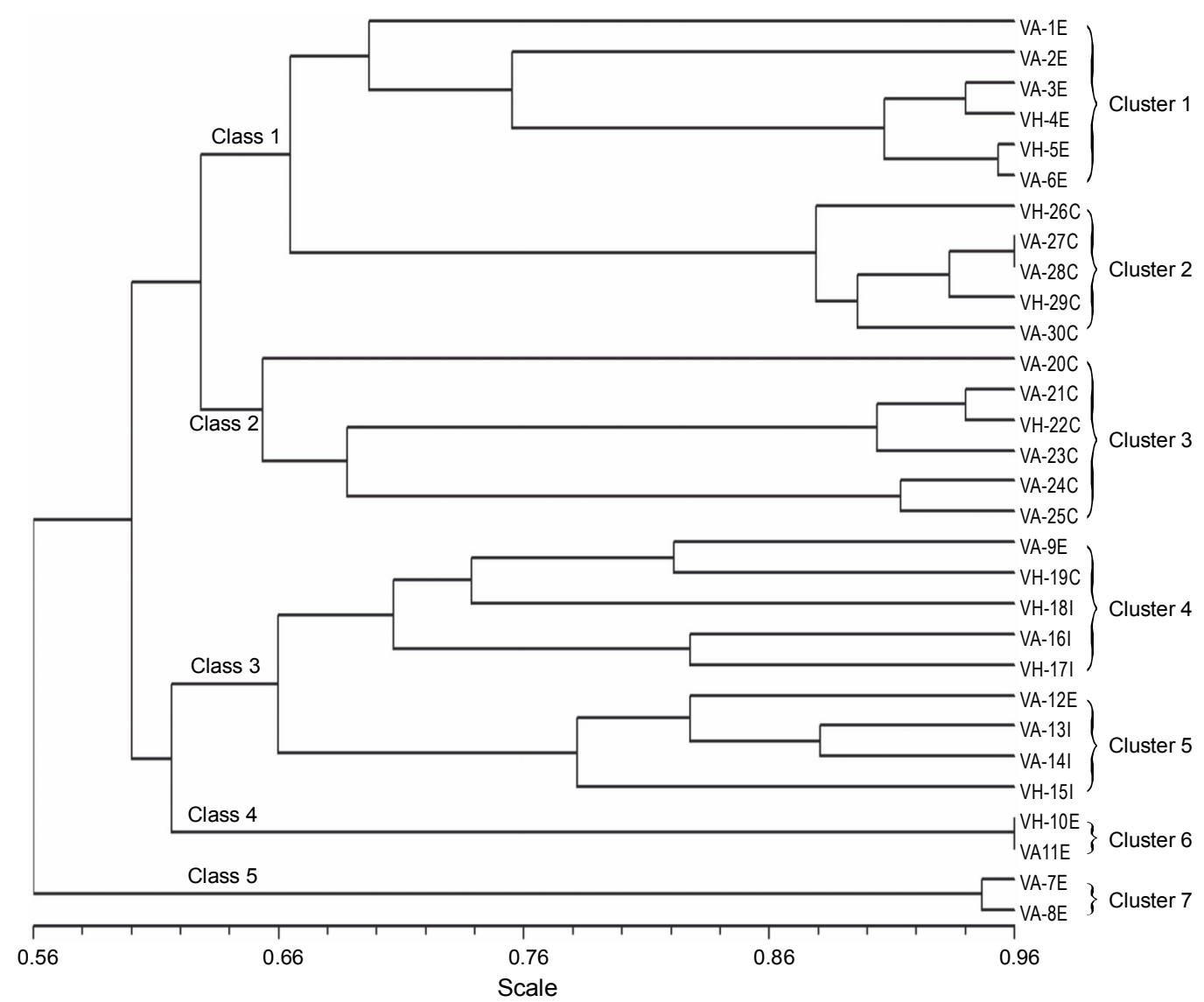

Fig. 2. Dendrogram showing the relationships between $V$. amygdalina types (bitter denoted as VA) and (less bitter denoted as $\mathrm{VH}$ )

collected from Esan Central and Esan West LGAs grouped in clusters 6 and 7. The geographical differentiation observed among Vernonia accessions in this study indicates that plant isolation by distance (IBD) - which may be due to the Founder effect as a result of a genetic drift - as well as a local adaptation could possibly explain the diversity observed in the investigated species. The Founder effect is the loss of genetic variation due to the establishment of a new population by a very small number of individuals from the original population; the gene and genotype frequencies of a new population may not represent these aspects of the original population (Provine, 2004). This observation is not surprising as Vernonia spp. is more often propagated vegetatively through the exchange of stem cuttings than via traditional methods. On the other hand, seeds are usually dispersed by wind over a restricted distance within each location. This implies that the genetic diversity could be narrow within the same geographical area, as only a few individuals could explain the diversity observed.
Some accessions, however, from different geographical locations sharing similar genetic profiles were observed and grouped into Cluster 4. Moreover, it was observed that there was no differentiation between bitter and less bitter ecotypes among accessions from the same location. This indicates that, although these plants may have different phytochemical constitution, the RAPDs decamer primers used in this study did not show any significant differentiation among accessions on the basis of the phytochemical constitution. This could be due to the dominant nature of RAPD markers and a random restriction of the DNA fragments, which do not differentiate between homozygous and heterozygotes markers, thereby masking the possible heterozygous nature of this trait.

\section{Conclusions}

This study - the first report of molecular characterization among Vernonia amygdalina accessions - showed that a significant genetic diversity is present within this 
species. The geographical differentiation observed between the plants even within the same state showed the presence of an enormous amount of genetic variability that can be exploited for the genetic improvement of this highly valued medicinal and nutritious traditional plant. We, therefore, suggest that the genetic diversity observed among Vernonia accessions studied was attributable to plant isolation by distance - secondary to geographical delimitation rather than phytochemical variation. Furthermore, we showed that the use of the RAPD marker system is an effective tool to evaluate genetic diversity and phylogenetic differences among $V$. amygdalina accessions. These results, therefore, provide a basis for further evaluation and exploitation of the available genetic diversity by using other marker systems such as the co-dominant microsatellites (SSRs), single-nucleotide polymorphisms (SNPs), and a sequence analysis to unravel greater genetic information and locate important mutations that could have been responsible for some of the observed phenotypic differences such as the intensities of bitterness.

\section{References}

Akah P.A., Okafor C.I. (1992) Hyperglycemic effect of Vernonia amygdalina Del. on experimental rabbit. Plant Med. Res. 1: 6-10.

Baig M.N.R., Grewal S., Dhillon S. (2009) Molecular characterization and genetic diversity of citrus cultivars by RAPD markers. Turk. J. Agric For. 33: 375-384.

Botstein D., White R.L., Skolnick M., Davis R.W. (1980) Construction of a genetic linkage map in man using restriction fragment length polymorphisms. Am. J. Hum. Genet. 32: 314-331.

Dellaporta S.L., Wood J., Hicks J.B. (1983) A plant DNA minipreparation: version II. Plant Mol. Biol. Rep. 1: 19-21.

Ebong P.E., Atangwho I.J., Eyong E.U., Egbung G.E. (2008) The antidiabetic efficacy of combined extracts from two continental plants: Azadirachta indica (A. Juss) (Neem) and Vernonia amygdalina (Del.) (African bitterleaf). Ame. J. Biochem. Biotechnol. 4(3): 239-244.

Evans W.C. (2002) Trease and Evans Pharmacognosy. 15th ed. WB Saunders Company; Bailliere Tindall: 197-393.

Hsiang T., Huang J. (2000) The use of RAPD markers to distinguish among juniper and cedar cultivars. Can. J. Bot. 78(5): 655-659.
Ijeh I., Nwugo V.O., Obidoa O. (1996) Comparative studies on the nutritive phytochemical and antimicrobial properties of two varieties of Vernomia amygdalina. Plant Proces. Res. Commun. 1: 71-75.

Ijeh I., Ejike C.E. (2011) Current perspectives on the medicinal potentials of Vernonia amygdalina Del. J. Med. Plants Res. 5: 1051-1061.

Iwu M.M., Okunji E., Akah P.A., Tempesta M.S., Carley D.G. (1996) Dioscoretine: the hypoglycemic principles of Dioscorea dumentorium. Planta Med. 56: 119-126.

Izevbigie E.B., Bryant J.L., Walker A. (2003) Edible Vernonia amygdalina leaf extract inhibitors extracellular signal-regulated kinesis and human breast cancer cell growth. J. Nutr. 133: 386-393.

Izevbigie E.B., Bryant J.L., Walker A. (2004) A novel natural inhibitor of extracellular signal-regulated kinases and human breast cancer cell growth. Exp. Biol. Med. 229: 162 $-168$.

Jaccard P. (1908) Nouvelles recherché sur la distribution florale. Bull. Soc. Vaudoise Sci. Nat. 44: 223-270.

Lisek A., Korbin M., Rozpara E. (2005) Using simply generated RAPD markers to distinguish between sweet cherry (Prunus avium L.) cultivars. J. Fruit Ornam. Plant Res. 14: 53-59.

Mkada-Driss I., Lahmadi R., Chakroun A.S., Talbi C., Guerbouj S., Driss M., Elamine E.M., Cupolillo E., Mukhtar M.M., Guizani I. (2014) Screening and characterization of RAPD markers in Viscerotropic Leishmania parasites. PloS ONE 9(10): e109773.

Monteleone I., Ferrazzini D., Belletti P. (2006) Effectiveness of neutral RAPD markers to detect genetic divergence between the sub-species uncinata and mugo of Pinus mugo Turra. Silva Fennica 40(3): 391-406.

Provine W.B. (2004) Ernst Mayr: Genetics and speciation. Genetics 167(3): 104-106.

Rabelo da Costa F., Perreira T.N.S., Vitoria A.P., DeCampos M.G., Rodriges R., DaSilva H., Perreira M.G. (2006) Genetic diversity among Capsicum accessions using RAPD markers. Crop Breed. Appl. Biotech. 6: 18-23.

Shafie B.M., Sayed M.Z., Ramisah M.S. (2009) Study of genetic variability of Wormwood capillary (Artemisia capillaris) using inter simple sequence repeat (ISSR) in Pahang region, Malaysia. Plants Omics J. 3: 127-134.

Ucheck F.F. (2004) Vernonia amygdalina Delile. [Internet] Record from Protabase. Grubben G.J.H., Denton O.A. (Editors). PROTA (Plant Resources of Tropical Africa), Wageningen, Netherlands. <http://database.prota.org/ search.htm> 